\title{
Bahiensol, a New Glycerolipid from a Cultured Myxomycete Didymium bahiense var. bahiense
}

\author{
Yuka Misono, ${ }^{a}$ Masami IshiBashi, ${ }^{*}, a$ and Akira Ito ${ }^{b}$ \\ ${ }^{a}$ Graduate School of Pharmaceutical Sciences, Chiba University; Chiba 263-8522, Japan: and ${ }^{b}$ Kyorin Pharmaceutical \\ Co., Ltd.; 2-5 Kanda-Surugadai, Chiyoda-ku, Tokyo 101-8311, Japan. \\ Received February 19, 2003; accepted March 6, 2003; published online March 6, 2003
}

\begin{abstract}
Bahiensol (1), a new glycerolipid with antimicrobial activity has been isolated from a cultured plasmodium of myxomycete Didymium bahiense var. bahiense and its planar structure was elucidated by spectral data.
\end{abstract}

Key words myxomycete; glycerolipid; cultured plasmodium

The myxomycetes (true slime molds) are an unusual group of primitive organisms that may be assigned to one of the lowest classes of eukaryotes. During our studies on the search for natural products from myxomycetes, ${ }^{1)}$ we recently investigated laboratory culture of myxomycetes and isolated sterols and pyrroloiminoquinone pigments. ${ }^{2)}$ Here we describe the isolation and structure elucidation of a new antimicrobial glycerolipid, bahiensol (1) from the cultured plasmodium of the myxomycete Didymium bahiense var. bahiense.

The fruit bodies of the myxomycetes $D$. bahiense var. bahiense were collected at Ina, Nagano Prefecture, Japan. The plasmodium of this myxomycete obtained in a plate culture ${ }^{2,3)}$ was mass cultured in the laboratory by agar plates with oatmeal. ${ }^{2,3}$ The harvested plasmodial cells were extracted with $90 \% \mathrm{MeOH}$ and $90 \%$ acetone, and the combined extract was partitioned between hexane and $90 \% \mathrm{MeOH}$. The $90 \% \mathrm{MeOH}$ layer was subjected to silica gel column chromatography, and the fraction exhibiting antimicrobial activity against Bacillus subtilis was further separated by the flash chromatography on ODS to give bahiensol (1) as a colorless oil.

Bahiensol (1) was shown to have the molecular formula $\mathrm{C}_{10} \mathrm{H}_{40} \mathrm{O}_{5}$ by the high resolution (HR)-FAB-MS data $(\mathrm{m} / \mathrm{z}$ 349.2950, $\left.[\mathrm{M}+\mathrm{H}]^{+}, \Delta-0.4 \mathrm{mmu}\right)$, implying that compound 1 possessed zero degree of unsaturation. The ${ }^{13} \mathrm{C}-\mathrm{NMR}$ spectrum of 1 in $\mathrm{CDCl}_{3}$ (Table 1) showed signals due to three oxymethines $\left(\delta_{\mathrm{C}} 64.1,70.1,72.6\right)$, three oxymethylenes $\left(\delta_{\mathrm{C}}\right.$ $70.6,70.9,72.1)$, one methyl $\left(\delta_{\mathrm{C}} 14.2\right)$ carbons. All other twelve signals were assignable to $s p^{3}$ methylene carbons $(\delta \mathrm{C}$ $22.7,25.5,25.6,25.8,29.4,29.7,29.8,31.9,36.5,37.4,37.5$, 37.6), and no signals due to $s p^{2}$ carbons were observed. Treatment of 1 with acetic anhydride and pyridine afforded a tetraacetate (2), implying that compound $\mathbf{1}$ contains four hydroxyl groups. Analyses of the ${ }^{1} \mathrm{H}-{ }^{1} \mathrm{H}$ correlation spectroscopy (COSY) and heteronuclear multiple bone connectivity (HMBC) spectra of $\mathbf{1}$ and $\mathbf{2}$ suggested the presence of a glycerol unit (C-1' to $\left.\mathrm{C}-3^{\prime}\right)$, and that $\mathrm{C}_{16}$ aliphatic chain $(\mathrm{C}-1$ to $\mathrm{C}-16$ ) is connected to $\mathrm{C}-3^{\prime}$ of glycerol unit through an

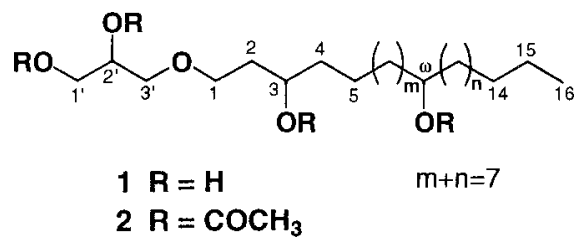

ether linkage. Two secondary hydroxyl groups $\left[\delta_{\mathrm{H}} 3.72(1 \mathrm{H}\right.$, $\mathrm{m}), 3.51(1 \mathrm{H}, \mathrm{m})]$ were included in the $\mathrm{C}_{16}$ aliphatic chain, and one of the two secondary hydroxyl groups was shown to be located on $\mathrm{C}-3$ position from the $\operatorname{COSY}\left(\mathrm{H}_{2}-1 / \mathrm{H}_{2}-2, \mathrm{H}_{2}-\right.$ 2/H-3) and HMBC correlations $\left(\mathrm{H}_{2}-1 / \mathrm{C}-2, \mathrm{H}_{2}-1 / \mathrm{C}-3, \mathrm{H}_{2}-\right.$ 2/C-1, H2-2/C-3). The position of the other secondary hydroxyl group (position ' $\omega$ ') was implied to be between C-6 to $\mathrm{C}-13$, and $\mathrm{MS} / \mathrm{MS}$ and ${ }^{1} \mathrm{H}$-detected heteronuclear multiple quantum coherence (HMQC)-total correlation spectroscopy (TOCSY) experiments were carried out to determine the exact position ' $\omega$ ', but were unsuccessful at this time. From these results, structure of bahiensol (1) was concluded to be 3-O-(3, $\omega$-dihydroxyhexadecanyl)-glycerol.

Bahiensol (1) is a previously unknown monoalkylglycerol, first isolated from the cultured plasmodium of the myxomycete Didymium bahiense var. bahiense. It was weakly positive on an antimicrobial activity test against Bacillus subtilis with a diameter of inhibition zone $12.5 \mathrm{~mm}$ at $500 \mu \mathrm{g}$ per paper disc ( $8 \mathrm{~mm}$ in diameter).

\section{Experimental}

General Procedures IR spectra were measured from samples on a $\mathrm{Hi}$ tachi 260-10 infrared spectrophotometer. NMR spectra were recorded on JEOL JNM ecp600 spectrometers. HR-FAB-MS was acquired on a JMS HX-110 mass spectrometer.

Organism and Culture The fruit bodies of the myxomycete Didymium bahiense (Order Physarales; Family Didymiaceae) were collected at Ina,

Table 1. ${ }^{1} \mathrm{H}$ - and ${ }^{13} \mathrm{C}-\mathrm{NMR}$ Data of Compound $\mathbf{1}$ (in $\mathrm{CDCl}_{3}$ )

\begin{tabular}{|c|c|c|}
\hline & \multicolumn{2}{|c|}{1} \\
\hline & $\delta_{\mathrm{H}}$ & $\delta_{\mathrm{C}}^{c}$ \\
\hline \multirow[t]{2}{*}{$1^{\prime}$} & $3.57 \mathrm{~m}$ & 64.1 \\
\hline & $3.65 \mathrm{~m}$ & \\
\hline $2^{\prime}$ & $3.80 \mathrm{~m}$ & 72.0 \\
\hline $3^{\prime}$ & $3.48^{a)} \mathrm{m}$ & 72.6 \\
\hline \multirow[t]{2}{*}{1} & $3.55 \mathrm{~m}$ & 70.1 \\
\hline & $3.67 \mathrm{~m}$ & \\
\hline \multirow[t]{2}{*}{2} & $1.67 \mathrm{~m}$ & 36.5 \\
\hline & $1.62 \mathrm{~m}$ & \\
\hline 3 & $3.72 \mathrm{~m}$ & 70.6 \\
\hline 4 & $1.48^{a)} \mathrm{m}$ & 37.4 \\
\hline$\omega$ & $3.51 \mathrm{~m}$ & 70.9 \\
\hline 14 & $1.26^{a)} \mathrm{m}$ & 31.9 \\
\hline 15 & $1.28^{a)} \mathrm{m}$ & 22.7 \\
\hline 16 & $0.81^{b)} \mathrm{t}, J=7.5 \mathrm{~Hz}$ & 14.2 \\
\hline
\end{tabular}

a) $2 \mathrm{H}$. b) $3 \mathrm{H}$. c) ${ }^{13} \mathrm{C}-\mathrm{NMR}$ signals of methylene carbons $\mathrm{C}-5-\mathrm{C}-13$ except $\mathrm{C}$ $\omega: \delta_{\mathrm{C}} 37.6,37.5,29.8,29.7,29.4,25.8,25.6$, and 25.5 . 
Nagano Prefecture, Japan, in August, 1999, and the procedures for the laboratory culture of this organisms are described previously. ${ }^{2}$ )

Extraction and Isolation The harvested plasmodial cells from 793 plate cultures $(9 \mathrm{~cm} \phi)$ were lyophilized to give $84.3 \mathrm{~g}$ of material (dry weight), which was extracted with $90 \% \mathrm{MeOH}(c a .900 \mathrm{ml} \times 2$ ) and $90 \%$ acetone $(750 \mathrm{ml} \times 1)$. The combined $\mathrm{MeOH}$ and acetone extract was partitioned between $90 \%$ aqueous $\mathrm{MeOH}(100 \mathrm{ml})$ and hexane $(25 \mathrm{ml} \times 3)$. The $90 \% \mathrm{MeOH}$ layer was evaporated under reduced pressure to give a residue $(6.5 \mathrm{~g})$, which was subjected to silica gel column chromatography (colum A; $4.0 \times 60 \mathrm{~cm}$ ) and eluted with $20-100 \% \mathrm{MeOH}$ in $\mathrm{CHCl}_{3}$. A fraction $(99.7 \mathrm{mg})$ of column A eluted with $20 \% \mathrm{MeOH}$ in $\mathrm{CHCl}_{3}$ was further separated by ODS column (colum B; $1.6 \times 24 \mathrm{~cm}$ ) eluted with $67-100 \% \mathrm{MeOH}$ in $\mathrm{H}_{2} \mathrm{O}$ to give bahiensol $(1,2.5 \mathrm{mg})$ in the fraction eluted with $80 \% \mathrm{MeOH}$ in $\mathrm{H}_{2} \mathrm{O}$. The fraction $(26.2 \mathrm{mg})$ of the column B eluted with $67-80 \%$ $\mathrm{MeOH}$ in $\mathrm{H}_{2} \mathrm{O}$ was separated again by ODS column $(1.0 \times 22 \mathrm{~cm})$ to give compound $\mathbf{1}(3.1 \mathrm{mg})$ additionally.

Bahiensol (1): Colorless oil; $[\alpha]_{\mathrm{D}}^{25}+23^{\circ}(c=0.5, \mathrm{MeOH})$; IR (film) $v_{\max }$ 3345, 2920, and $1460 \mathrm{~cm}^{-1}$; ${ }^{1} \mathrm{H}$ - and ${ }^{13} \mathrm{C}-\mathrm{NMR}$ (Table 1); FAB-MS $\mathrm{m} / \mathrm{z}$ $349(\mathrm{M}+\mathrm{H})^{+}$; HR-FAB-MS $\mathrm{m} / z$ 349.2950 [Calcd for $\mathrm{C}_{19} \mathrm{H}_{40} \mathrm{O}_{5},(\mathrm{M}+\mathrm{H})$ 349.2954]. Tetraacetate $(2,0.9 \mathrm{mg})$ was prepared by treatment of bahiensol $(\mathbf{1}, 0.9 \mathrm{mg})$ with acetic anhydride $(0.1 \mathrm{ml})$ and pyridine $(0.2 \mathrm{ml})$ at room temperature for $14 \mathrm{~h}$.
2: ${ }^{1} \mathrm{H}-\mathrm{NMR}\left(\mathrm{CDCl}_{3}\right) \delta_{\mathrm{H}} 5.16\left(1 \mathrm{H}, \mathrm{m} ; \mathrm{H}-2^{\prime}\right), 4.95(1 \mathrm{H}, \mathrm{m} ; \mathrm{H}-3), 4.85(1 \mathrm{H}$, m; H- $\omega), 4.32(1 \mathrm{H}$, dd, $J=11.5,3.6 \mathrm{~Hz}$; H-1'), $4.15(1 \mathrm{H}, \mathrm{dd}, J=11.5,6.3 \mathrm{~Hz}$; H-1' $), 3.53\left(2 \mathrm{H}, \mathrm{m}, J=7.1 \mathrm{~Hz} ; \mathrm{H}_{2}-3^{\prime}\right), 3.46\left(2 \mathrm{H}, \mathrm{m} ; \mathrm{H}_{2}-1\right), 2.08(3 \mathrm{H}, \mathrm{s}), 2.06$ $(3 \mathrm{H}, \mathrm{s}), 2.03(6 \mathrm{H}, \mathrm{s}), 1.79\left(2 \mathrm{H}, \mathrm{m} ; \mathrm{H}_{2}-2\right)$, and $0.87\left(3 \mathrm{H}, \mathrm{t} ; \mathrm{H}_{3}-16\right) ;{ }^{13} \mathrm{C}-\mathrm{NMR}$ $\left(\mathrm{CDCl}_{3}\right) \delta_{\mathrm{C}} 14.1,20.7,21.0,21.2,21.3,22.6,25.1,25.2,25.3,29.2,29.4$, $29.5,31.8,34.1,34.1,34.2,34.4,62.9,68.1,69.1,70.2,71.6,74.3,170.3$, 170.6, 170.6, and 170.9.

Acknowledgments This work was partly supported by a Grant-in-Aid from the Ministry of Education, Culture, Sports, Science and Technology of Japan and by a Grant-in-Aid from the Uehara Memorial Foundation and the Japan Securities Scholarship Foundation. We are grateful to Dr. K. Yamaguchi and Dr. H. Seki of our university for instrumental analyses.

\section{References}

1) Ishikawa Y., Ishibashi M., Yamamoto Y., Hayashi M., Komiyama K., Chem. Pharm. Bull., 50, 1126-1127 (2002).

2) Ishibashi M., Iwasaki T., Imai S., Sakamoto S., Yamaguchi K., Ito A., J. Nat. Prod., 64, 108-110 (2001).

3) Ishikawa Y., Kono Y., Iwasaki T., Misono Y., Nakatani S., Ishibashi M., Ito A., Matsumoto J., Nat. Med., 55, 312 (2001). 